\title{
ФИЛИПЧУК СВІТЛАНА,
}

кандидат історичних наук, доцент кафедри релігієзнавства і теологіï,

Національний університет "Острозька академія", м. Острог

\section{ТРАНСФОРМАЦІї НОВИХ МЕДІА ХРИСТИЯНСЬКИХ КОНФЕСІЙ УКРАЇНИ}

Авторка досліджує видозміни нових медіа українських церков. Доведено, що інтернетсередовище спричинило сплеск діяльності електронних конфесійних $3 \mathrm{MI}$ різних видів, що зробило їх новими засобами для донесення місії церкви в українському суспільстві. Проаналізовано офіційні сайти конфесій, соціальні мережі, блогосферу та ін. на предмет окреслених Е. Тоффлером ознак нових медіа, як-то: інтерактивність, мобільність, зворотність і можливість взаємозв'язку. Зроблено висновок, що християнські нові медіа групи-спільноти в соціальних мережах, форуми, сайти, блоги тощо - органічно поєднують виконання медійних та конфесійних функцій, трансформують зовнішню і внутрішню комунікацію в церковному середовищі, адже на їхніх платформах активно творять контент не лише церковні прес-служби, відповідальні за ті чи інші напрямки церковного служіння, але й прості віряни, а також невоцерковлені, утім зацікавлені духовними питаннями користувачі. Із новими медіа пов'язані явища віртуалізації та консюмеризму релігії. Медіатизація християнських конфесій України через призму інтернет-середовища відбувається через глобальну зміну людини, відтак і церкви, яка прагне діалогу 3 людиною та спільнотами людей засобами нових медіа.

Ключові слова: нові медіа; християнські конфесії; релігійна діяльність; медіатизація.

Постановка проблеми, її актуальність. У XXI ст. релігійне життя активно переміщується в інтернет-середовище. Сьогодні кожен, хто має доступ до мережі, може шукати нові форми вираження релігійного досвіду, не перебуваючи фрізично на місці поклоніння або особисто не контактуючи зі священиком/духівником. Цифрова епоха пропонує віртуальні богослужіння, кібер-молитви, дискусії/форуми, музичне поклоніння тощо. Новий форум, який надає для християнських конфесій інтернет-середовище, трансформує традиційні види соціальної та релігійної взаємодії.

Стан вивчання проблеми. Проблематика "релігія і кібер-простір", яку активно розробляють учені Копенгагенського університету під керівництвом Мортена Т. Хейсгаарда та Маргіт Варбург, насичена такими темами: як релігійний досвід створюється й утілюється в інтернеті, як впливають на формування віри чинники безмежного вибору, відсутності релігійного авторитету та конфлікт між визнаними і невизнаними фоорами богослужіння, як зберегти в інтернеті релігійну ідентичність тощо [Hojsgaard, Warburg, 2007].

3 появою комп'ютерних телекомунікацій і комп'ютерних мереж церква отримала нові засоби для виконання своєї місії. С. Д. О'Леарі, вивчаючи функціонування кібер-релігії, наголошує: "Комп'ютерне опосередковане спілкування являє собою зсув, порівняний із величиною до революції Гутенберга" [O'Leary, 1996: 781]. А в іншій своїй праці вчений підкреслює, що друкарський верстат, а сьогодні це мережа інтернет, який свого часу був переконливою ознакою настання завершальної стадії "великої місії" євангелізації всього світу й наближення біблійних "останніх днів", $€$ "інструментом для завершення божественного плану. ... Комп'ютерні тех- нології можуть направду принести месіанські чудеса" [O'Leary, 2010: 44].

Метою дослідження $€$ аналіз трансформаційних процесів нових медіа християнських конфесій України.

Виклад основного матеріалу. Римо-католицька церква, наголошуючи на необхідності донесення до широкої аудиторії, що живе в середовищі комп'ютерної культури, євангельського повідомлення, у своїх документах наголошує на інтерактивності нових медіа: "Нові технології, полегшивши спілкування й діалог серед ії членів, значно зміцнили їхню єдність. Миттєвий доступ до інфоормації дає можливість церкві поглиблювати діалог із сучасним світом" [Перун ред., 2004: 315]. Папа Франциск у Посланні до 48-го Всесвітнього дня суспільних комунікацій закликає католиків бути мобільними в нових медіа: "Сміливо ставаймо мешканцями цифрового світу. Церква потребує бути присутньою у світі комунікації для того, щоб вести діалог із сучасними людьми й допомагати їм зустрічати Христа. ... Революція, що відбувається в комунікативних медіа та в інформаційних технологіях, $є$ величезним і захопливим викликом; нам потрібно відповісти на цей виклик зі свіжою енергією та уявою, щоб передавати іншим красу Бога" [Послання Папи Франциска, 2014]. Митрополит УПЦ МП Володимир наголошував на місії церкви в сучасному суспільстві, підкреслюючи, що "проповідь за допомогою сучасних $3 \mathrm{Ml}$ - це важливе і вкрай необхідне служіння церкви в сучасному світі" [Володимир, 2011: 232].

Із року в рік в Україні активно розвивається онлайнаудиторія. Так, динаміка 2018 р. засвідчує, що 70 \% населення тією чи іншою мірою активно користувалися інтернетом, що на 11 \% більше, ніж у 2017 р. Середньостатистичний українець проводить в інтернеті 5,5 год.

\section{СХІД № 5 (157) вересень-жсовтень 2018 р.}


на добу [Cтатистика интернет-аудитории Украины, 2018]. Відтак через канал електронних 3MI - інтернет-сайтів, соціальних мереж і блогів - соціальні комунікації церкви здобули нові виклики, можливості та перспективи.

У науковій літературі активно послуговуються синонімічними термінами "електронні медіа" або "нові медіа". Узагальнивши напрацювання медіа-дослідників, Н. Зражевська дає таке визначення: нові медіа - це "інтерактивні електронні видання й нові форми комунікації виробників контенту зі споживачами. ...Цим терміном позначають процес розвитку цифрових, мережевих технологій і комунікацій у медійній галузі" [Зражевська, 2013: 70]. Профресор Мічиганського університету Рассел Нойман так трактує поняття "нові медіа": "New media - це новий формат існування 3MІ, постійно доступних на цифрових пристроях, у яких відбувається активна участь користувачів у створенні та розповсюдженні контенту" [Neuman, 2010: 3].

Е. Тофффлер у своїй класичній праці "Метаморфози влади", обґрунтовуючи теорію Трьох хвиль і аналізуючи сьогоденні взаємовідносини між 3МІ та владними інституціями, економічною системою, релігією, наголошує, що новим медіа властиві такі шість характеристик: інтерактивність, мобільність, зворотність, можливість взаємозв'язку, повсюдність та глобалізація. Ці ознаки цілковито трансформують не тільки наші повідомлення одне одному, але й спосіб нашого мислення, поведінки, світогляду [Тофрфлер, 2003: 439]. Д. Матісон наголошує на істотній відмінності медіа-практики в інтернет-середовищі від діяльності друкованих й аудіовізуальних $3 \mathrm{Ml}$ "Це взаємовідношення, які сформувалися між творцем та споживачем тексту. ... Онлайн-медіа формують величезний, безмежний простір із практично безкінечною кількістю видів дискурсу" [Матисон, 2017: 231].

Відповідно до звіту Департаменту у справах релігій та національностей Міністерства культури України, усі православні мають 56 електронних 3МІ, католики - 42, протестанти - понад 34 [Звіт про мережу, 2018]. Утім, цей звіт не відображає кількості блогів, тематичних груп у соцмережах, каналів на відеохостингах та ін. В інтернет-мережі $є$ численні веб-каталоги певних конфесій та ресурсів, які генерують релігійну інформацію та аналітику. Це, зокрема, каталоги на таких ресурсах: Релігійно-інформаційна служба України (risu.org.ua/ua/ index/resourses/webcatalog/intro_catalog), православні ЗМІ на сайті Синодального інформаційно-просвітницького відділу УПЦ МП (http://festzmi.org/), християнські церкви (churches.com.ua), християнські сайти на порталі invictory.com (invictory.com/sites/), корисні лінки на сайті газети "Путь" (asd.in.ua/links), інтернет-ресурси УГКЦ на ї̈ офіційному сайті в розділі "УГКЦ сьогодні" (ugcc.ua) тощо.

Проаналізувавши більшість інтернет-медіа християнських конфесій України, наголосимо, що структурно вони подібні й містять такі елементи: офріційна церковна інфрормація, суспільно-релігійний новинний контекст України і світу, посилання (каталог) на інші християнські ресурси, головні напрями роботи конфесії/місцевої церкви (соціальний, освітній, дитячий, молодіжний, сімейний, паломницьке служіння тощо), бібліотека (текстова, відео-, аудіо-), документи церкви, богословські джерела, мапа єпархій (храмів, монастирів, місій, громадських релігійних організацій тощо), блоги тощо.

Напрацювання українських учених в аспекті виділення ними функцій, які виконує інтернет-простір у житті церков загалом та конфесійні мас-медіа зокрема, у своїй монографії узагальнила С. А. Козиряцька, розпо- діливши функції християнських медіа-ресурсів на два види: медійні (інформаційна, комунікаційна (зовнішня і внутрішня комунікація), новинна, ціннісно-регулювальна, рекреативна, створення архівів і депозитаріїв, баз даних, зв'язки з громадськістю, установлення зв'язків між членами громади) та власне конфесійні (місіонерство, євангелізація, катехізація, прозелітизм, координація служінь церкви, благовістя, апологетична, транслювання інформації релігійного змісту або тієї, що стосується релігійної діяльності, яка відбувається за межами кібер-простору, згуртування й утримання вірян через формування необхідного інформаційного поля) [Козиряцька, 2017: 30]. Водночас медійники-практики наголошують, що 3Мl, зокрема нові медіа, у житті церкви виконують три функції: зовнішня комунікація (можливість відкрити себе для сучасного світу), внутрішня комунікація (діалог у межах церковної організації та церковних спільнот) та рецептивний діалог із суспільством (можливість через точки дотику пізнати світогляд сучасників і відповісти на нього християнським посланням) [Бабинська та ін., 2012: 34].

Конфесійний медіа-простір у сегменті електронних ЗMІ аналізуватимемо за ознаками новітніх медіа, виокремленими Е. Тоффрлером.

Інтерактивність нових медіа християнських конфесій України виявляється в прагненні до різновекторного діалогу. Лорне Л. Давсон [Lorne L. Dawson] у дослідженні "Медіація релігійного досвіду в кібер-просторі" наголошує: "Комп'ютерна комунікація - групове, за своєю суттю соціальне, явище. Ця реальна інтерактивність залучає людей до соціального життя в мережі та пов'язує користувачів із наявною соціальною дійсністю. Інтернет, на відміну від інших комунікаційних каналів, спроможний наблизитися до інтерактивності офлайнових стосунків" [Dawson, 2005: 31]. Приміром, мультимедійний релігійний портал \#ОТЧЕНАШ, який творить команда протоієрея Георгія Коваленка на чолі з інтернет-дияконісою Юлією Комінко, так артикулює свою налаштованість до персоніфікованої розмови: "Ми пропонуємо Вам персонального помічника і путівника у світі Православія. "Отець Інтернет" - це група експертів, яка ... спробує відповісти на будь-яке Ваше запитання та знайти потрібну для Вас інформацію або порадити чисте інформаційне джерело. Кожен читач матиме можливість стати експертом" [ОТЕЦЬ-IHTEPHET, 2018]. Хоча А. Кураєв наполягає, що "православ'я нетехнологічне" [Кураев, 2011: 53], утім, значна кількість православних новітніх медіа переконує в іншому й свідчить про неминучі процеси віртуалізації і цієї конфесії. Отже, інтернет може бути форумом для людей, які не можуть знайти місця для подібних дискусій у їхніх громадах. Водночас цей майданчик дозволяє відвідувачам зрозуміти, що вони не самотні у своїх духовних пошуках, переживаннях та сумнівах.

Форуми на різні духовно-релігійні теми, які $є$ на багатьох християнських ресурсах, дозволяють відвідувачеві (невоцерковленому чи вірянинові) того чи іншого сайту порушити наболілу тему, вести полілог, у такий спосіб стаючи частково і редактором, і творцем нового медіа-продукту. Так, на протестантському порталі InVictory користувач, авторизувавшись, може додати тему-пост. Щоби уможливити діалог на форумі в рамках християнської моралі, модератори пропонують дотримуватися певних правил: не використовувати нетолерантну та дискримінаційну лексику щодо співрозмовника, не порушувати політичних тем, поважати віросповідні особливості всіх конфесій, не висловлюватися негативно про служителів інших конфесій, під час діа- 
логу керуватися християнськими морально-етичними принципами [Форум, 2018].

В онлайнових форумах на християнських сайтах і групах у соцмережах, які відкриті для людей із різними світоглядами, дискусії здебільшого протиставляються за критеріями "віруючий"/"невіруючий". Ця поляризація настільки потужна й чітко окреслена, що деякі християни, які хочуть порушити альтернативні для своєї конфесії погляди, зазвичай утримуються від цього, адже бояться "дозволити" "невіруючим" дістати перевагу в дискусії чи тематичній суперечці. Відтак ці та подібні процеси в нових медіа викликають трансформації індивідуальної релігійної свідомості та діяльності, оскільки, як уважають М. Левхейм і А. Г. Ліндерман у праці "Побудова релігійної ідентичності в інтернеті", "індивіди беруть на себе відповідальність та забов'язання поза традиційними формами релігійного лідерства" [Hojsgaard, Warburg, 2005: 136]

Доволі розлоге в популярних соціальних мережах Facebook та Instagram представництво церков, християнських видавництв, благодійних організацій, конфесійних навчальних закладів, християнських музичних гуртів, різноманітних форм позакультової діяльності (молодіжні табори, фестивалі, семінари, форуми тощо), персонально окремих священиків та ін. Група в соціальній мережі - це спільнота у віртуальному світі, яка або створена з метою спілкування для вірян, або ж місійного/євангелізаційного спрямування для широкого загалу. Контент таких груп - це здебільшого оперативна текстова та візуальна інформація, короткі цитати із Біблії, вислови відомих богословів і християнських лідерів, посилання на різноманітні музичні (кліпи, концерти, карооке християнських пісень та гімнів), текстові (книги, статті), відеохостинги (проповіді, фільми, мотиваційні ролики, вірусна реклама тощо), опитування, дискусії, обговорювати теми яких може кожен охочий член віртуальної спільноти. Наприклад, священик парафії Української греко-католицької церкви (УГКЦ) отець Василь Германюк із Тернопільщини в неділю й на значні християнські свята організовує прямі трансляції в Instagram. Він мотивує свою діяльність так: "Якщо молода особа прокидається вранці й першим їі кроком є відкриття Instagram, щоб глянути, хто що там лайкнув і кинув новенького, - я пропоную духовну альтернативу" [SMM для парафіян, 2018].

Сергій Степанюк, директор відділу комунікації Церкви адвентистів сьомого дня в Україні, радячи християнській молоді активно використовувати власні акаунти в соцмережах для проповіді й благовістя, наголошує на важливості двосторонньої комунікації через нові медіа: "Люди хочуть бачити реальних людей, читати те, що пишуть реальні люди, спілкуватися більше з реальними людьми у соцмережах" [Християнська молодь $і$ соцмережі, 2018].

Блогосфера - потужний сегмент медіа-середовища, якому також властиві інтерактивність та діалог. Рассел Нойман наголошує, що блогосфера - "це справді відкритий ринок ідей - іноді неслухняний і грубий, іноді дорадчий і навіть поетичний. Найважливішим питанням порядку денного є визначити, у який спосіб ця яскрава царина думок, інформації та дезінформації має і може продовжувати взаємодіяти 3 основними 3МІ та широкою громадськістю" [Neuman, 2016: 10]. На порталі RISU знаходимо чималий кластер блогів священиків, богословів, релігійних діячів, конфесійних журналістів, експертів та ін. Автори у своїх дописах порушують релігійні, суспільно-політичні, соціальні, освітні, мо- ральні та ін. проблеми сьогодення вірян і пересічних українців, активно ведучи діалог із читачами. Християнська блогосфера - це можливість для її авторів і читачів вийти за інформаційні "храмові стіни", винести на широкий загал свої не завжди "канонічні" думки й переживання, спілкування у форматі "віч-на-віч" із собою та Іншим, межова ситуація між сакральним та профанним.

Активний блогер ("Українська правда", "Обозреватель") та дописувач на власній сторінці Facebook прессекретар УПЦ КП Євстратій (Зоря), говорячи про моральні засади спілкування в мережі, підкреслює: "Ми всі живемо в такому світі і в таких обставинах, що не завжди маємо можливість живого спілкування, а інтернет, соціальні мережі дають його. Однак будь-яке спілкування має бути відповідальним, а в мережах, де можна спілкуватися анонімно, на християнина, на священика лягає особлива відповідальність. ... Тож добрі діла мають свідчити про нас і в інтернеті" [Священики в соціальних мережах, 2018]. Греко-католицький священик Олег Кобель, душпастир молодіжного руху "Справжня любов чекає", блогер, уважає, що в роботі з молоддю він не бачить кращої альтернативи для церкви, як інтернет: "Те, що колись ми називали "вулицею", сьогодні справедливо можемо назвати інтернетом. ... Будьхто зі служителів може озброїтися клавіатурою, щоби за її допомогою вирушити з Христом на пошуки заблукалих ягнят..." [Простір для проповідування, 2013: 9].

Цікавий блог на платформі власного акаунту у Facebook веде Тарас Дятлик - керівник відділу розвитку освіти Євро-Азіатської акредитаційної асоціації євангельських навчальних закладів. Під хештегом \#Щепки він постить свої роздуми на теми суспільства, церкви, богослов'я, культури, політики, сім'ї, молитви тощо. Оскільки Тарас Дятлик - знана особистість не тільки в євангельському просторі, але й у середовищі вчених-гуманітаріїв [див., наприклад, Dyatlik, 2018], його дописи викликають і продукують жваві дискусії та активний екуменічний та науковий діалог.

Спостерігається процес формування так званої контекстної теології в нових медіа як рефлексії, що виникає в людей у суспільно-релігійних обставинах та їхніх конкретних життєвих ситуаціях. Так, книга журналіста Олексія Гордєєва "Церква на Майдані" на своїх сторінках містить чимало таких миттєвих рефлексій: осмислення світоглядної позиції й ролі протестанта під час карколомних політичних змін у країні - Революції Гідності - через призму постів на сторінках у соцмережах [Гордеев, 2015].

Часто рефлексії-дописи релігійних експертів, лідерів думок та журналістів на власних сторінках у соцмережах здатні викликати суспільне обговорення тих чи інших суспільно-релігійних тем. Так, відома журналіст і консультант із комунікацій РКЦ в Україні Олена Кулигіна на платформі власного акаунту в Facebook 31 липня 2018 року розмістила пост про проведення занять із йоги у Львівському органному залі, який водночас $є$ чинним римо-католицьким храмом Марії Магдалени. Згодом фото, які, як вірусна реклама, миттєво поширилися інтернетом, спровокували появу різних публікацій на християнських та світських ресурсах щодо доцільності проведення таких практик у культових будівлях. Додаткового обурення читачам додало ще й те, що заняття з цієї "нехристиянської фізкультури" відбулися в час, коли Україна святкувала 1030-річчя свого хрещення. 1 серпня католицький портал credo.pro публікує матеріал "'Йоги в храмі не буде": влада Львова відреагувала на обурення громадськості". 2 серпня на сайті 
tvoemisto.tv у розділі "Блоги" було опубліковано розлогу статтю Олени Кулигіної "Чи є місце для йоги в католицькому храмі?". На інцидент відреагував на своїй сторінці у мережі Facebook Андрій Москаленко, заступник міського голови Львова з питань розвитку, а на сайті "Духовна велич Львова" можновладець зазначив: "У першу чергу - просимо вибачення у всіх, в кого проведення даного заходу викликало обурення. Команда Органного залу розуміє і визнає, що сакральна споруда має свою атмосферу та правила, які потрібно поважати" [Кулигіна, 2018].

Мобільність як ознака новітніх медіа засвідчує використання нових технологій у царині комунікації. Ідеться першочергово про можливості планшетів і смартфонів, які практично стали "комп'ютеризованою правою рукою". Станом на 2018 рік 45 \% українців $є$ постійними користувачами смартфонів, що в п'ять разів більше, ніж 2013 року [В Україні кількість користувачів..., 2018].

Соцопитування 2007 року, здійснене компанією Gfk Ukraine на замовлення Центру "Нова Європа", засвідчило, що більшість української молоді (86 \%) мають упродовж дня доступ до інтернету й використовують цю можливість здебільшого для комунікації (72 \% респондентів віком від 14 до 17, а також 58 \% - від 25 до 29 років). Переважають такі види діяльності молоді в інтернеті: соцмережі, музика, перегляд і завантаження фрільмів тощо. Серед соціальних мереж, якими користується молодь - Вконтакте, Instagram, Facebook, Twitter, а також месенджери Viber i Telegram [Українське покоління Z, 2017: 120].

Завдяки мобільності "тут і тепер", відомі християнські лідери, активні громадські активісти-християни та й прості віряни наживо транслюють через мережу Facebook події, на яких перебувають. Зокрема, Руслан Кухарчук, журналіст, медіа-менеджер, голова Асоціації "Новомедіа", транслював у центрі Києва - від Софійської площі до майдану Незалежності - ходу за сімейні цінності (2 червня 2018 року). Також щонеділі на сторінці "Живе ТБ" у Facebook відбувається пряма трансляція Божественної літургії з Патріаршого Собору УГКЦ Воскресіння Христового.

Telegram-канал "Українського Товариства Реформації" пропонує своїм читачам статті, огляди, знайомство з авторами і їхніми творами, електронні книги пуританських, реформатських авторів, а також істориків церкви для зручного читання на будь-якому пристрої, відеосемінари та проповіді. Так, через інтернет-ресурс "Служебник реформаторської церкви", на який за посиланням скеровують із каналу, підписники мають змогу безкоштовно замовити книги (наприклад, два томи тлумачення на книгу Буття Жана Кальвіна).

Зворотність, за Е. Тофрфлером, - це "здатність передавати інформацію від одного 3MІ до іншого" [Tофрфрлер, 2003: 442]. Головною особливістю цієї ознаки нових медіа $€$ конвергенція, тобто поєднання різноманітного контенту (текстового й аудіовізуального) на одній інтернет-платорормі. Зворотній зв'язок із читачами/глядачами забезпечується через форуми, соціальні мережі, приватне електронне листування та групи в месенджерах, наприклад у Viber i Telegram.

Так, католицький портал credo.pro містить інформацію, яка постійно оновлюється: оперативні новини 3 України та католицького світу, аналітичні публікації, інтерв'ю, відеобесіди, підкасти, розділ молитовних прохань, блоги, паломництва, молитви, літургії, благодійна допомога, богословські та церковні тексти тощо. Архі- тектоніка офріційного сайту УПЦ КП cerkva.info містить такі мультимедійні розділи: церква (уся інформація про структуру церкви: синодальні установи, архієреї, мапа єпархій, статутні та церковні документи тощо), Патріарх (біографія, проповіді, інтерв'ю тощо), православні новини з України та світу, документи, церковний календар, бібліотека (богословські та літургійні книги), соцмережі (розміщено відео, присвячене ювілею Патріарха Філарета, а також відеочати з єпископом Євстратієм).

Надзвичайно розвинені за ознакою зворотності нові медіа українських протестантів. Так, на офріційному сайті Української церкви християн віри євангельської chve.org.uа є відеозвернення старшого єпископа УЦХВЄ Михайла Паночка, наприклад, щодо водного хрещення 23 липня 2018 року у водах Дніпра, приуроченого до державного свята 1030-річчя Хрещення Русі-України, а також посилання на YouTube-канал медіа-служіння УЦХВЄ, де розміщено відеопроповіді, трансляції щорічного Всеукраїнського з"їзду християнської молоді в Малині тощо. Сайт Української уніонної конференції церкви адвентистів сьомого дня uuc.adventist.ua пропонує трансляції богослужінь та відеопроповіді відомих адвентистських пасторів. Сайт Всеукраїнського союзу церков євангельських християн-баптистів надає можливість своїм відвідувачам прослуховувати Біблію в онлайн-режимі, переглянути відео 3 відвідин пасторами військових ЗСУ, які служать на передовій у зоні АТО, форум пасторів-баптистів, де обговорюються актуальні й болючі для служителів теми, інтерв'ю-обговорення (зокрема 3 головою Союзу Валерієм Антонюком про діалог поколінь у церкві), відеозвернення, коментарі (так, офріційна заява братства ЄХБ у зв'язку з оприлюдненням у ЗМІ та соціальних мережах інформації про дії ВСЦ ЄХБ щодо новозбудованого баптистського храму Миру, любові та єдності в Києві), конференції (пасторські конференції можна переглянути на ресурсі pastoronline.org.ua), акценти (відеоролики до 5 хв. про дотримання свободи совісті в різних країнах світу).

Цікавою формою процесу зворотності новітніх медіа $є$ видання текстів блогів та постів із соціальних мереж у книжковому форматі. Так, видавництво "Свічадо" 2016 р. видало книгу голландського священика Мішеля Ремері "Твіти з Богом". Проект "Твіти з Богом" (Tweeting with GOD) знайомить читача з основами віри в Бога на основі Святого Письма та вчення католицької церкви. Отець Мішель Ремері щотижня проводив молодіжні зустрічі в одній із церков неподалік Амстердама, щоб обговорювати все (не існувало жодних заборонених тем), що цікавить молодих людей про віру, про їхнє життя та про Бога. Так сорормувалася книга із 200 "твітів", а також пояснення до них (назва "твіти" походить від соціальної мережі Twitter, у якій дозволений обсяг тексту до 140 знаків) [Твіти з Богом, 2018].

Відомий український релігійний фрілософ та теолог Михайло Черенков у період Революції Гідності активно постив на своїй сторінці в мережі Facebook есеї щодо суспільно-політичної ситуації, які згодом увійшли до видання "Протестантська етика і дух остмодернізму" (автори М. Черенков та В. Бачинін), у якому через духовно-інтелектуальне осмислення взаємовідношення між протестантським світоглядом та агресивним пострадянським середовищем порушується питання, що означає бути протестантом у неототалітарній Росії та на київському Майдані. Хоча досвід в авторів різний, але вони говорять про Реформацію як єдину надію і для суспільства, і для церкви [Бачинин, Черенков, 2015].

Можливості нових мас-медіа використовують не 
тільки офріційні церковні організації, але й опозиційно/ критично/інтелектуально налаштовані віряни. Misanthropic Church - релігійний журнал гостросоціальної критики із 5,4 тис. підписників у Facebook, слоган "Формування прогресивного порядку денного для віруючих". У мережі Misanthropic Church на сайті medium.com позиціонує себе як "Товариство думаючих, адекватних християн, які готові відверто обговорювати злободенні теми, що стосуються церкви та навколишнього світу". Зокрема, на ресурсі розміщено актуальні, на думку редакції, статті для сучасної церкви, головно протестантських конфесій. Так, привертає увагу переклад статті із The Economist "Як Лютер став вірусом", головна теза якої збігається з метою діяльності Misanthropic Church: "Соціальні мережі, не дозволяючи приглушити голос опозиції, можуть демонструвати рівень революційних настроїв у суспільстві, а разом із новими технологіями вони $€$ прекрасним каталізатором суспільних змін" [Как Лютер стал вирусом, 2018].

Контент-аналіз засвідчує порушення на платформі Misanthropic Church y Facebook гострих тем церковних фрінансів, публічних дій християнських лідерів, корупційних дій певних церковників та релігійних організацій, що позиціонують себе як християнські, загравання з політиками задля отримання дивідендів для своєї структури тощо. Провокативні теми "на межі", які подано в саркастичному стилі, викликають запеклі дискусії, посилюють опозиційне налаштування редакції щодо сучасних виявів протестантизму в Україні. Спільно 3 Місійним союзом євангелічних громад України, Молодіжною асоціацією релігієзнавців онлайн-журнал Міsanthropic Church творить і реальну комунікацію в стилі інтелектуально-критичного бекґраунду. Зокрема, зустріч 24.02.2018 р. на тему "Питання віри у світському кінематографрі", під час якої культурологи, релігієзнавці, публіцисти порушували тему, як у сучасному світському кінематографрі розкриваються питання віри та церковного життя [Religion is coming, 2018].

\section{Висновки}

Цифровий світ трансформує суспільство, культуру, людину. Церква, бажаючи розмовляти з внутрішніми та зовнішніми аудиторіями через посередництво зрозумілого каналу комунікації, активно використовує інтернет-середовище. Християнські мережеві ЗМІ у своїй діяльності органічно поєднують виконання медійних та конфесійних функцій. Нові медіа християнських конфесій - групи-спільноти в соціальних мережах, форуми, блоги тощо - перманентно доступні активним та пасивним прихильникам усіх християнських конфесій України. Нові медіа трансформують зовнішню і внутрішню комунікацію в церковному середовищі, адже на їхніх платформах активно творять контент не лише церковні прес-служби, відповідальні за ті чи інші напрямки церковного служіння, але й прості віряни, а також невоцерковлені, утім зацікавлені духовними питаннями користувачі.

Інтернет значно підвищує можливості для індивідуального шукача знайти інформацію про традиційні, а також альтернативні християнські організації. Порівняно низька вартість та незначні зусилля надихнули багатьох людей та спільноти поширювати своє повідомлення на аудиторію, що постійно зростає. Через перегляд онлайн-трансляцій богослужінь, богословських конфреренцій, семінарів на різні практичні релігійні теми, участь у тематичних форумах на християнських ресурсах люди всіх вікових та соціальних категорій хо- чуть і можуть долучатися до релігійних переконань та практик.

Соціальна поведінка у віртуальних християнських спільнотах та середовищах - це нове явище, яке дозволяє дослідникам спостерігати, документувати й аналізувати, як воцерковлені й невоцерковлені люди адаптують та приймають закономірності поведінки у відповідь на різні умови, які отримують в тій чи іншій соціальній групі, що залежить від іï існування за допомогою технології, пов'язаної із комп'ютером чи смартфоном.

Із новими медіа пов'язані явища віртуалізації та консюмеризму релігії. Медіатизація християнських конфесій України через призму інтернет-середовища відбувається через глобальну зміну людини, відтак і церкви, яка прагне діалогу із людиною та спільнотами людей засобами нових медіа.

\section{ЛТЕРАТУРА}

Бачинин В., Черенков М. Протестантская этика и дух остмодернизма. Київ: Книгоноша, 2015. 376 с.

В Україні кількість користувачів смартфонів зросла у п'ять разів. URL: https://glavcom.ua/country/society/v-ukrajini-kilkistkoristuvachiv-smartfoniv-zrosla-u-pyat-raziv-ekspert-480621.html (дата звернення: 12.10.2018).

Гордеев А. Церковь на Майдане. Київ: Книгоноша, 2015. $304 \mathrm{c}$.

Звернення Блаженнішого Митрополита Київського і всієї України Володимира до учасників VII Міжнародного фестивалю православного кіно та ЗМІ "Покров". Володимир (Сабодан). Доповіді, промови, звернення. Київ: Видавничий відділ УПЦ, 2011. $422 \mathrm{c}$.

Звіт про мережу церков і релігійних організацій в Україні станом на 01.01.2018 p. URL: https://risu.org.ua/ua/index/resourses/ statistics/ukr_2018/70440/ (дата звернення: 11.09.2018).

Зражевська Н. І. Нові медіа і нові форми комунікації в медіа культурі. Current issues of mass communication. 2013. Issue 14. C. 70-75. URL: http://er.ucu.edu.ua/bitstream/handle/1/ 1015/apmk_2013_14_16.pdf?sequence=1\&isAllowed=y (дата звернення: 07.09.2018).

Как Лютер стал вирусом. URL: https://medium.com/ @misanthropic (дата звернення: 07.09.2018).

Козиряцька А. В. Мережеві християнські видання українського медіапростору: монографія. Запоріжжя: Просвіта, 2017. 192 c.

Кулигіна О. Чи є місце для йоги в католицькому храмі. URL: http://tvoemisto.tv/blogs/chy_ie_mistse_dlya_yogy_v_katolytskomu hrami 94864.html (дата звернення: 19.09.2018).

Кураев А. Православие: точки роста. Москва: Никея, 2011. 208 c.

Матисон Д. Медиа-дискурс. Анализ медиа-текстов, 2-е изд. Пер. с англ. Харьков: Гуманитарный Центр, 2017. 264 с.

Послання Папи Франциска на 48-й Всесвітній день суспільних комунікацій. URL: http://credo.pro/2014/02/110721 (дата звернення: 14.09.2018).

Простір для проповідування. Католицький вісник. 2013. № 20. С. $40-41$.

Священики в соціальних мережах. URL: http://old.dyvensvit.org/articles/2191.html (дата звернення: 15.09.2018).

SMM для парафіян: Український священик опанував Instagram. URL: https://nachasi.com/2018/03/03/smm-dlyaparafiyan/ (дата звернення: 16.09.2018).

Статистика интернет-аудитории Украины. URL: https:// seoukraine.com.ua/statistika-internet-auditorii-ukrainy-iispolzuemyh-ustroystv/ (дата звернення: 11.09.2018).

Твіти 3 Богом. URL: https://svichado.com/vydannya_dlya_molodi_i_ditey/tvity_z_bohom.html (дата звернення: 10.09.2018). 
Тоффрлер Э. Метаморфозы власти: Пер. с англ. Москва: ООО Издательство АСТ, 2003. 669 с.

Українське покоління Z: цінності та орієнтири. Результати загальнонаціонального опитування. Київ: Центр Нова Європа, 2017. 135 с

Форум InVictory. Условия пользования. URL: http:// www.invictory.com/terms.html\#communication (дата звернення: 16.09.2018)

Християнська молодь і соцмережі. URL: http://stepstohope.in.ua/hrystyianska-molod-i-sotsmerezhi/ (дата звернення: 15.09.2018).

Християнське послання в комп'ютерній культурі. Церква і соціальна комунікація: Найголовніші документи католицько церкви про пресу, радіо, телебачення, Інтернет та інші медіа. Упоряд. і наук. ред. М. Перун. Львів: Вид-во Українського католицького університету, 2004. 440 с.

Бабинська С., Завадська Ю., Карапінка М., Кулигіна О. Церква і медіа: 7 кроків до порозуміння. Б. М.: Ездра, 2012. 240 c.

\#ОТЕЦЬ-IHTЕРНЕТ Ваш персональний експерт. URL: http:// www.отченаш.укр/fish/index.html (дата звернення: 19.09.2018).

Dawson, 2005: The mediation of religious experience in cyberspace. Religion and Cyberspace. Edited by Morten Hojsgaard, Margit Warburg. New York: Taylor \& Francis, 2005. P. 15-37.
Dyatlik Taras. Methodology of the research of the conflation in the Epistle to Galatians. Skhid. 2018. № 3 (155). P. 74-77. DOI: 10.21847/1728-9343.2018.3(155).139835.

Hojsgaard M. (ed.), Warburg, M. (ed.). Religion and Cyberspace. London: Routledge, 2005. 207 p. DOI: https://doi.org/ 10.4324/9780203003572.

Lövheim M., Linderman A. G. Constructing religious identity on the Internet. Edited by Morten Hojsgaard, Margit Warburg. New York: Taylor \& Francis, 2005. P. 121-137.

Neuman R. Media, Technology, and Society. Theories of Media Evolution. Digital Culture Books. University of Michigan Press: Michigan, 2010.

Neuman R. The Digital Difference. Evolving Media Technology and the Theory of Communication Effects. 2016. Harvard University Press. DOI: https://doi.org/10.4159/9780674969858.

O'Leary S. D. Cyberspace as Sacred Space. Communicating Religion on Computer Networks. Journal of the American Academy of Religion. 1996. 64 (4). Pp. 781-808.

O'Leary S. D. Utopian and dystopian possibilities of networked religion in the new millennium. Digital Culture Books. University of Michigan Press: Michigan, 2010. P. 44.

Religion is coming: питання віри у світському кінематогpaqpi. URL: http://rellab.org.ua/24-02-religion-coming (дата звернення: 14.09.2018).

Fylypchuk Svitlana,

PhD in Historical Sciences, Associate Professor of Religious and Theology Studies,

National University "Ostroh Academy", Ostroh

\section{TRANSFORMATIONS OF THE NEW MEDIA OF THE CHRISTIAN CONFESIONS IN UKRAINE}

The author investigates the changes of the new media in Ukrainian churches. It has been proved that the Internet environment has triggered the activities of various electronic confessional media, making them new means of bringing the mission of the Church into Ukrainian society. The official websites of the denominations, social networks and others are analyzed for the purpose of the emerging features of the new media by $E$. Toffler, such as interactivity, mobility, reciprocity and the possibility of interconnection. It is concluded that the Christian new media, such as social networks' groups, forums, sites, blogs, etc. are organically combining the media and denomination's functions, also transform the external and internal communication in the church environment. Relatively low cost and insignificant efforts have inspired many Christians and churches to spread their message to an expanding audience. People of all age and social categories join religious beliefs and practices through watching online broadcasts of church worship, theological conferences, seminars, participation in thematic forums on Christian resources. Social behavior in virtual Christian communities and environments is a new phenomenon that allows researchers to observe, document, and analyze how church and non-church people adapt and accept patterns of behavior in response to various conditions that are received in a particular social group that depends on its existence through technology linked to a computer or smartphone. The phenomenon of virtualization and consumerism of religion are associated with the new media. Mediation of the Christian denominations of Ukraine through the prism of the Internet environment is due to the global change of a person, and thus the Church, which seeks a dialogue with a community of people through the means of the new media.

Key words: new media; Christian confessions; religious activity; mediatization.

\section{REFERENCES}

\# FATHER-ONLINE Your personal expert. Available at: http: //www.atchenash.ukr/fish/index.html.

Address of His Beatitude Metropolitan Volodymyr of Kyiv and All Ukraine to the participants of the VII International Orthodox Cinema and Media Festival "Pokrov". 2011. Volodymyr (Sabodan). Reports, speeches, appeals. K.: Publishing Department of the UOC, 422 p. (ukr).

As Luther became a virus. Available at: https://medium.com/@misanthropic.

Bachinin, V., Cherenkov, M. 2015. Protestant ethics and the spirit of ostmodernism. K.: Knigonosha, 376 p. (rus)

Christian message in computer culture. 2004. Church and Social Communication: The most important documents of the Catholic Church about the press, radio, television, the Internet and other media. Orderly and Sciences. Ed. M. Perun. L.: View of the Ukrainian Catholic University, 440 pp. (ukr).

Christian youth and social networks. Available at: http://stepstohope.in.ua/hrystyianska-molod-i-sotsmerezhi/.

Church and Media: 7 Steps to Understanding. 2012. Babinska, S., Zavadska, Yu., Karapinka, M., Kuligina, O. Ezra, 240 p. (ukr).

Dawson, 2005: The mediation of religious experience in cyberspace. Religion and Cyberspace. Edited by Morten Hojsgaard, Margit Warburg. New York: Taylor \& Francis, 2005.p.15-37. 
Dyatlik, T 2018. Methodology of the research of the conflation in the Epistle to Galatians. Skhid, no. 3(155), pp. 74-77. DOI: http:// skhid.kubg.edu.ua/article/view/139835/139131.

Forum InVictory. Terms of use. Available at: http://www.invictory.com/terms.html\#communication.

Gordeyev, A. 2015. Church on the Maidan. K.: Knigonosha, 304 p. (rus).

Hojsgaard, M. (Ed.), Warburg, M. (Ed.). (2005). Religion and Cyberspace. London: Routledge. 207 p. DOI: https://doi.org/10.4324/ 9780203003572.

In Ukraine, the number of smartphone users has increased fivefold. Available at: https://glavcom.ua/country/society/v-ukrajinikilkist-koristuvachiv-smartfoniv-zrosla-u-pyya-raziv-ekspert-480621.html.

Internet audience statistics of Ukraine. Available at: https://seoukraine.com.ua/statistics-internet-auditorii-ukrainy-i-ispolzuemyhustroystv/.

Kozyryatska A, 2017. Network Christian editions of the Ukrainian media space: monograph. Zaporozhye: Prosvita, 192 p. (ukr).

Kuligina, O. Is there a place for yoga in the Catholic church. Available at: http://tvoemisto.tv/blogs/chy_ie_mistse_dlya_yogy_-

v_katolytskomu_hrami_94864.html.

Kuraev, A. Orthodoxy: Growth points. M.: Nikeya, 2011. 208 p. (rus).

Lövheim, M., Linderman, A. G. 2005. Constructing religious identity on the Internet. Edited by Morten Hojsgaard, Margit Warburg. New York: Taylor \& Francis, p.121-137.

Matison, D. 2017.Media Discourse. Analysis of media texts. from english Kh.: Publishing House, Humanitarian Center, 264 p. (ukr). Neuman, R. 2010. Media, Technology, and Society. Theories of Media Evolution. Digital Culture Books, University of Michigan Press: University of Michigan Library.

Neuman, R. 2016. The Digital Difference. Evolving Media Technology and the Theory of Communication Effects. Harvard University Press. DOI: https://doi.org/10.4159/9780674969858.

O'Leary, S. D. 1996. Cyberspace as Sacred Space. Communicating Religion on Computer Networks, Journal of the American Academy of Religion. 64 (4), pp. 781-808.

O'Leary, S. D. 2010. Utopian and dystopian possibilities of networked religion in the new millennium. Digital Culture Books, University of Michigan Press: University of Michigan Library, P.44.

Priests in social networks. Available at: http://old.dyvensvit.org/articles/2191.html.

Religion is coming: The question of faith in secular cinematography. Available at: http://rellab.org.ua/24-02-religion-coming.

Report on the Network of Churches and Religious Organizations in Ukraine as of 01.01.2018. URL: https://risu.org.ua/en/index/ resourses/statistics/ukr_2018/70440/.

SMM for parishioners: The Ukrainian priest mastered Instagram. Available at: https://nachasi.com/2018/03/03/smm-dlya-parafiyan/. Space for preaching. 2013. Catholic Bulletin. №20 pp. 40-41.

The Epistle of Pope Francis on the 48th World Public Communications Day. Available at: http://credo.pro/2014/02/110721.

Toffler, E. 2003. Metamorphoses of power: from english. M .: OOO Publishing house ACT, 669 p. (rus).

Tweets with God. Available at: https://svichado.com/vydannya_dlya_molodi_i_ditey/tvity_z_bohom.html.

Ukrainian generation Z: values and benchmarks. 2017. Results of a nationwide poll. K.: Center New Europe, 135 p. (ukr).

Zrazhevska, N. I. 2013. New media and new forms of communication in media culture. Current issues of mass communication. Issue 14. P. 70-75. Avaialble at: http://er.ucu.edu.ua/bitstream/handle/1/1015/apmk_2013_14_16.pdf?sequence=1\&isAllowed=y.

(c) Филипчук Світлана

Надійшла до редакції 02.10.2018 